\title{
Litter input in cerrado, cerradão and forest environments in Amazon, Brazil
}

\author{
Maria Clécia Gomes Sales ${ }^{1} \mathbb{\oplus}$, Milton Cesar Costa Campos ${ }^{1} \mathbb{\oplus}$, Thalita Silva Martins ${ }^{1} \mathbb{0}$, \\ Elilson Gomes de Brito Filho ${ }^{1} \oplus$, Elyenayra Nogueira Pinheiro' ${ }^{1}$, José Maurício da Cunha1 ${ }^{1}$, \\ Vânia da Silva Fraga ${ }^{2} \oplus$, Fernando Gomes de Souza ${ }^{3}[$

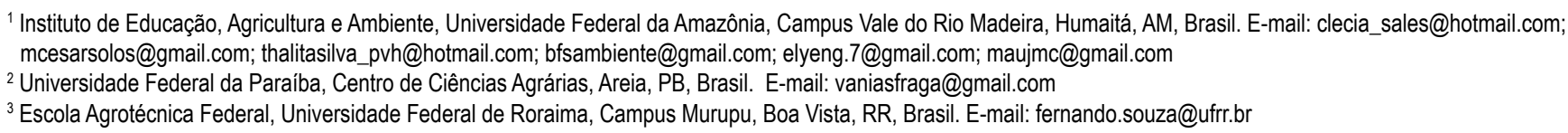

ABSTRACT: Production and decomposition of litter is one of the most important entry sources of nutrients into the soil layers, especially in Amazonian environments, where the soils with low natural fertility are. The study aimed to quantify the litter-forming material intake in cerrado, cerradão and forest environments in the Amazon. Ten conical collectors were set up in each study environment. Collections were monthly held for one year. After each collection, the fractions of leaves, branches, reproductive material and barks were all screened. The total litter production was of 4.24; 11.48 and $12.58 \mathrm{Mg} \mathrm{ha}^{-1}$ year $^{-1}$ in the cerrado, cerradão and forest areas, respectively. The monthly deposition in the cerrado ranged from $0.13 \mathrm{Mg} \mathrm{ha}^{-1}$ to $0.75 \mathrm{Mg} \mathrm{ha}^{-1}$, while in the cerradão the values were 0.52 and $2.18 \mathrm{Mg} \mathrm{ha}^{-1}$ and in the forest, they were between $0.70 \mathrm{Mg} \mathrm{ha}^{-1}$ and $1.97 \mathrm{Mg} \mathrm{ha}^{-1}$. The analysis and interpretation of the results allowed concluding that the litter deposition, for both the forest and cerradão areas, is higher than the one for the cerrado area, having a greater deposition in a period of water scarcity observed for all areas of this study, with the leaves fraction having contributed with the highest percentage.

\section{Aporte de serapilheira em ambientes de cerrado, cerradão e floresta} na Amazônia, Brasil

RESUMO: A produção e decomposição de serapilheira constitui uma das vias de entrada mais importantes de nutrientes nas camadas do solo, principalmente em ambientes amazônicos, onde há ocorrência de solos com baixa fertilidade natural. $O$ estudo teve como objetivo quantificar o aporte do material formador da serapilheira em ambientes de cerrado, cerradão e floresta na Amazônia. Foram instalados em cada ambiente de estudo dez coletores cônicos. As coletas foram realizadas mensalmente durante um ano. Após cada coleta, realizou-se a triagem das frações folhas, galhos, material reprodutivo e cascas. A produção total de serapilheira foi de 4,24; 11,48 e 12,58 $\mathrm{Mg} \mathrm{ha}^{-1}$ ano-1 $^{-1}$ nas áreas de cerrado, cerradão e floresta, respectivamente. A deposição mensal, no cerrado variou de $0,13 \mathrm{Mg} \mathrm{ha}^{-1}$ a 0,75 $\mathrm{Mg} \mathrm{ha}^{-1}$, no cerradão os valores foram de 0,52 e 2,18 Mg ha-1 e na floresta, os valores variaram entre $0,70 \mathrm{Mg} \mathrm{ha}^{-1} \mathrm{e} 1,97 \mathrm{Mg} \mathrm{ha}^{-1}$. A análise e interpretação dos resultados permitiram concluir que a deposição de serapilheira para as áreas de floresta e cerradão são superiores que para a área de cerrado, sendo observado para todas as áreas deste estudo, maior deposição em período de escassez hídrica, tendo a fração folhas contribuído com 0 maior percentual.

Palavras-chave: biomassa; ciclagem de nutrientes; resíduos vegetais 


\section{Introduction}

Litter production is one of the most important entry sources of vegetation nutrients into the soil, representing the production of deciduous material from the vegetation cover as well as the deposition of animal waste (Matos et al., 2017). This production process is especially important in forests from soils with low natural fertility, as is the case of most Amazonian soils (Quesada et al., 2011).

Within this approach, several studies on litter input have been conducted in the Amazonian biome (Silva et al., 2009; Almeida et al., 2015; Malhi et al., 2015). However, since the Amazon can be divided into up to 26 phenological regions (Silva et al., 2013), generalizing these results for the entire biome of inadequate manner (Almeida et al., 2015). Based on this premise, there are different physiognomies in the westernmost part of the Amazon, from dense forests to natural fields in the southern Amazonas and northern Rondônia. These natural fields have characteristic physiognomic aspects, occupying an estimated area of $3,418 \mathrm{~km}^{2}$ (Vidotto et al., 2007), and having the presence of forest, cerrado and cerradão physiognomies found in this geographic environment.

The forest is located at the points with highest landscape and better drainage, functioning as a drainage divide and showing a dense forest physiognomy (Campos et al., 2012). The cerrado has a more uniform aspect formation, composed by lower trees (Campos et al., 2012) and subjected to fire pressure in the dry period, which is a frequent event that influences the vegetation dynamics. The cerradão, however, presents as its predominant physiognomy the tree-shrub component (Braun \& Ramos, 1959).

Over the years, these environments have suffered impacts on their natural cover due to anthropogenic activities such as timber extraction, conversion of forests into pasture and land grabbing. Although the Amazonas state has the lowest rate of deforested area in the Legal Amazon, its southern portion has become a new agricultural frontier, since it has had the largest deforestation fronts in the state (Yanai et al., 2011).

In this matter, studies in regions with high deforestation rates and consequently rapid and continuous changes in the forest structure should be a priority in order to understand what the effects of these said changes are, in both the short and long terms, on the litter production (Almeida et al., 2015). This very production has become a fundamental tool in indicating the conservation stage of natural and reforested environments nowadays. Therefore, the aim of this study was quantifying the input of litter-forming material in cerrado, cerradão and forest environments in the Amazon, Brazil.

\section{Materials and Methods}

\section{Localization and characterization of the study areas}

The study was conducted in three areas: forest (7034'10" S and 637'41.77" W), cerrado (7034.27'37" S and 637'57.28" W) and cerradão (7034'19.70" S and 637'49.66" W), contemplating an transition area between dense forest ecosystems and natural fields. They are located in the southwest Brazilian Amazon, municipality of Humaitá, south Amazonas, at the margins of the 319 Brazilian National Road (BR 319), in an area belonging to the 54th Jungle Infantry Battalion from the Brazilian Army (Figure 1).

These areas are generically characterized by the presence of three distinct environments: the forest, having an established dense forest physiography with the presence of species such as Euterpe precatoria, Vismia guianensis, Orbignya speciosa, Oenocarpus bacaba and Mabea subsessilis (Campos et al., 2012). The cerrado, composed by vegetation with a more shrubby aspect (Campos et al., 2010) with the occurrence of species from the genera Andropogon and Paspalum as well as twisted and spaced trees, such as the Curatella americana I. and Eupatorium sp. (Campos et al., 2012), which are subject to fire, acting as a disturbing element of the system. Lastly, the cerradão is composed by shrubs and a fine secondary vegetation ("capoeira") (Santos et al., 2012), having among its most important species the Sclerolobium paniculatum, Himatanthus sucuuba and Mabea caudata (Campos et al., 2012).

The source material of the soils from these regions comes from the alluvial sediments, which have originated chronologically in the Holocene period (Brazil, 1978). In these environments, there are Haplic Cambisols (Inceptisols), Haplic Gleysols (Alfisols) and Red Argisol (Ultisols), all characterized by low natural fertility and located in areas of flat and smooth undulating relief (Campos et al., 2012).

Regarding the climatic characterization, according to the Köppen classification, the region belongs to the A group (Tropical Rainy Climate) and the Am climatic type (monsoon rains) (Brazil, 1978). In addition, according to the Brazilian National Institute of Meteorology (INMET), the region rainy season occurs between October and March and the dry season between June and August, with the rest of the months considered as a transition period. Figure 2 illustrates the mean

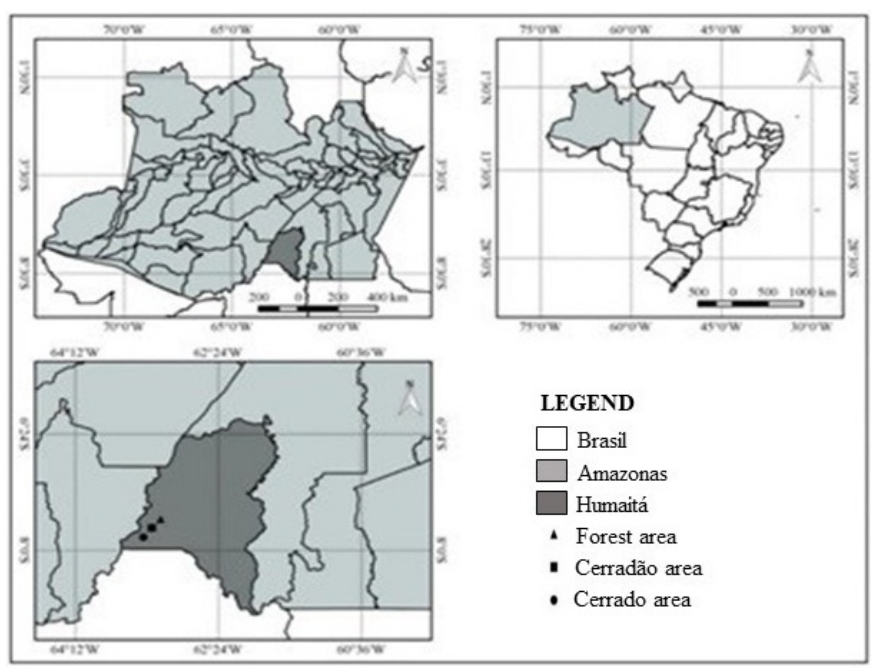

Figure 1. Location of the studied areas. Map of Brazil, highlighting the Amazonas state and the study areas on the map of the municipality of Humaitá - AM. 
monthly distribution of precipitation and temperature from April 2018 to March 2019, the period in which the collections took place.

The greatest rainfall precipitation was in January, with a drastic reduction in June. The maximum air temperature was of 27.95 oC in September 2018, a transition month between the dry and rainy period, and the minimum temperature was of 24.34 o $\mathrm{C}$ in June 2018 , at the start of the dry period. (Figure 2). In a similar fashion, the relative air humidity had a maximum value of $87 \%$ in December and a minimum of $68 \%$ in July.

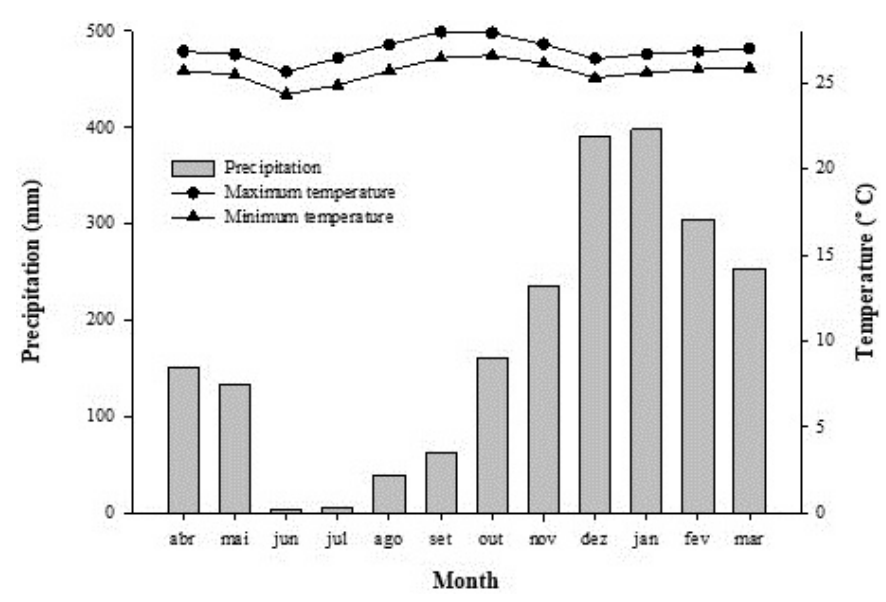

Source: INMET. Brazilian National Institute of Meteorology.

Figure 2. Monthly mean of climatic data on precipitation and temperature from April 2018 to March 2019, obtained at the climatological station in the municipality of Humaitá - AM.

\section{Litter input evaluation}

For the litter input evaluation, an area of approximately one (1.0) hectare was delimited in each studied environment (cerrado, cerradão and forest), in which 10 conical collectors with an area of $0.21 \mathrm{~m}^{2}$ (perimeter equal to $1.62 \mathrm{~m}$ ) were randomly distributed. These collectors were constructed with a $3 / 4$ " tube made of polyethylene plastic material, having also a nylon net bottom with a $1 \mathrm{~mm}$ mesh for preventing the loss of smaller material and enabling the water exit (Figure 3).

The collectors were set up $30 \mathrm{~cm}$ above the ground for avoiding litter loss due to the action of microorganisms. Each one was previously identified with a number and the litter production was evaluated considering the material deposited in the suspended collectors (Figure 4).

Collections took place monthly during the period from April 2018 to March 2019. The procedure for collecting the material inside the collector consisted of manual selection. After each collection, the fractions of leaves, branches, reproductive material (flowers and fruits) and barks went under screening and subsequently drying in an oven with forced air circulation at $45{ }^{\circ} \mathrm{C}$ until reaching constant weight, followed by weighting on a precision scale to obtain the dry weight. The obtained data allowed estimating the monthly and annual means of the litter produced by the studied environments, as well as the percentage of each evaluated fraction.

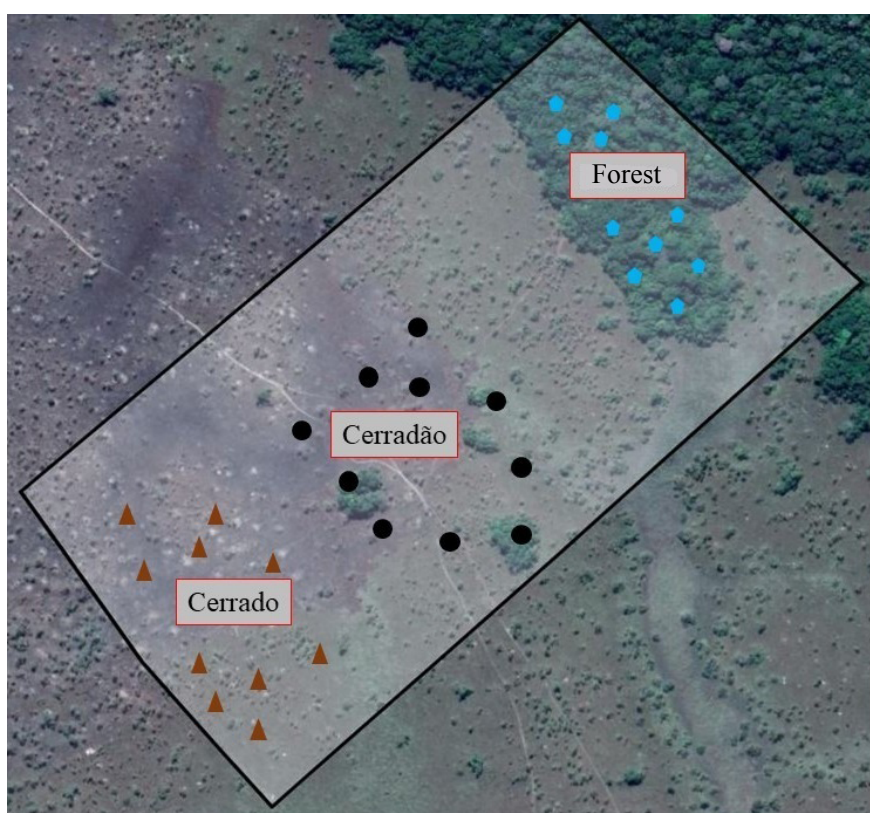

Figure 3. Positioning sketch of the conical collectors set up in the cerrado, cerradão and forest areas in the south Amazonas during the period from April 2018 to March 2019.
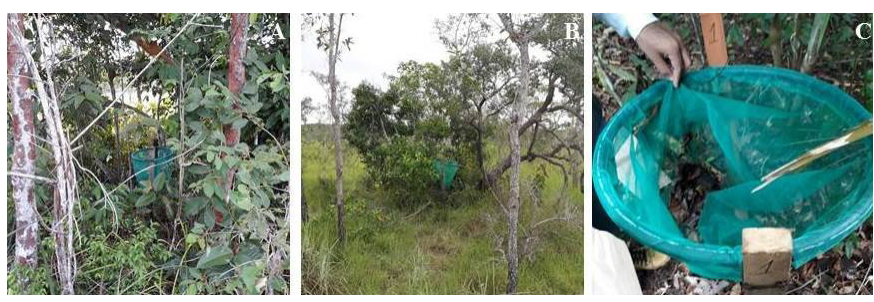

Figure 4. View of the litter collectors set up in the study areas. A- cerrado; B- cerradão; C- forest.

Monthly ( $\left.\mathrm{Mg} \mathrm{ha}^{-1}\right)$ and annual ( $\mathrm{Mg} \mathrm{ha}^{-1}$ year ${ }^{-1}$ ) litter inputs were represented by transforming the dry weight of each fraction (grams) in relation to the collector area $\left(0.21 \mathrm{~m}^{2}\right)$.

In order to check for possible differences in the litter input of the different areas, the analysis of variance was performed using a completely randomized design (CRD) with 10 replicates. Means found for the variables were compared using the Tukey test with a 5\% significance level, performed using the computer program Statistical Package for Social Sciences (SPSS), version 12.5 .

\section{Results and Discussion}

\section{Litter input}

The total amount of litter produced was of $4.24 ; 11.48$ and $12.58 \mathrm{Mg} \mathrm{ha}^{-1}$ year $^{-1}$ for the cerrado, cerradão and forest areas, respectively. The total annual stock in the cerradão area equaled the quantified one in the forest, which had values higher than the verified for cerrado (Figure 5A). However, considering the great structural difference of the cerrado in relation to the other areas, higher inputs values in the forest and cerradão are accepted, since the cerrado has a semi-open vegetation with spaced trees, small and with little biomass per area unit (Matos et al., 2017). 
In relation to the monthly litter production, the input in cerrado varied from $0.13 \mathrm{Mg} \mathrm{ha}^{-1}$ in June to $0.75 \mathrm{Mg} \mathrm{ha}^{-1}$ in September. In the cerradão, the values found were 0.52 and $2.18 \mathrm{Mg} \mathrm{ha}^{-1}$ in the months of January and September, respectively. As for the forest, the lowest value found was 0.70 $\mathrm{Mg} \mathrm{ha}^{-1}$ in January and the highest was $1.97 \mathrm{Mg} \mathrm{ha}^{-1}$ in August (Figure 5B).

The amount of material input to the forest over the year equaled the quantity input to the cerradão, with the exception of December, month in which all areas differed, with the highest production in the forest and the lowest in the cerrado (Figure 5B).

Giácomo et al. (2012) observed a litter production pattern equal to the one verified in this very study in the forest area, with greater inputs from July to September and a considerable decrease from October onwards. The authors concluded that this pattern is due to the seasonality influence on this vegetation type.

The seasonality effect on the litter production is well discussed by authors such as Brasil et al. (2017) and Holanda et al. (2017). According to them, there are two patterns for the annual litter production in Brazilian ecosystems: the first one occurs due to a greater deposition in the dry period of the
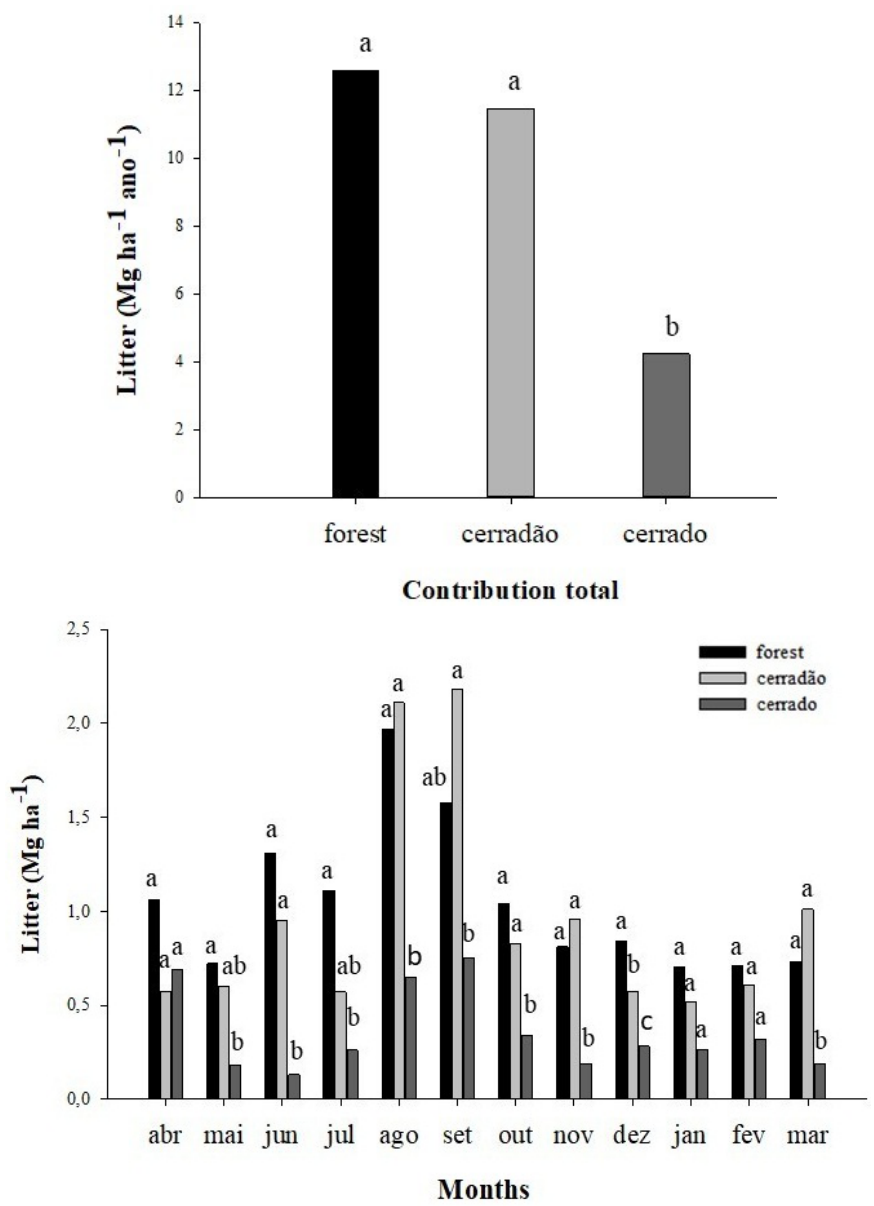

Figure 5. Litter input in cerrado, cerradão and forest areas in southern Amazonas during the period from April 2018 to March 2019. Same letters in the column do not differ by Tukey test at 5\% level. A) Total litter input; B) Monthly litter input. year, a characteristic phenomenon of Amazonian ecosystems, in mesophytic and cerrado forests; the second one consists of the largest deposition in the wet season, common in restingas and Atlantic forests.

When analyzing the litter input in the cerradão area, there was no difference in the months of April, May, July, January and February in relation to the cerrado area (Figure 5B). In these environments, the largest litter production recorded was at the end of the dry period (August and September), since September is considered a transition month in the region and the maximum rainfall recorded was still relatively low (Figure 2). Silva et al. (2007) also found in their study that the largest litter input occurred during the dry season in the areas of cerrado sensu stricto, cerradão and transition forest. These results suggest the notion that the greatest reduction in plant material occurs regulated by the lowest water input for the vegetation (Almeida et al. 2015).

However, the small amount of material input to the cerrado and cerradão areas in the months of June and July may be related to fires in the region during this period, a phenomenon that is common in both cerrado and cerradão environments during the dry season. Ostensibly, this is the common ecological strategy among the savanna species (Antoneli \& Francisquini, 2015). Moreover, an optimum litter accumulation is required for such fires to take place.

Figure 6 displays the total percentage values from the litter fractions input. The percentages from the fractions of leaves and reproductive material tended to increase in cerradão and forest areas, while the fractions of branches and barks had a higher percentage in the cerrado area. This pattern may be related to the large number of dry branches and barks that expire during the dry season, a characteristic cerrado phenomenon, and are easily detached by the action of rainwater and wind (Silva et al., 2007).

Leaves represented a greater proportion in all environments, averagely contributing with $54.5 \%, 68.8 \%$ and $68.6 \%$ in cerrado, cerradão and forest areas, respectively (Figure 6). According

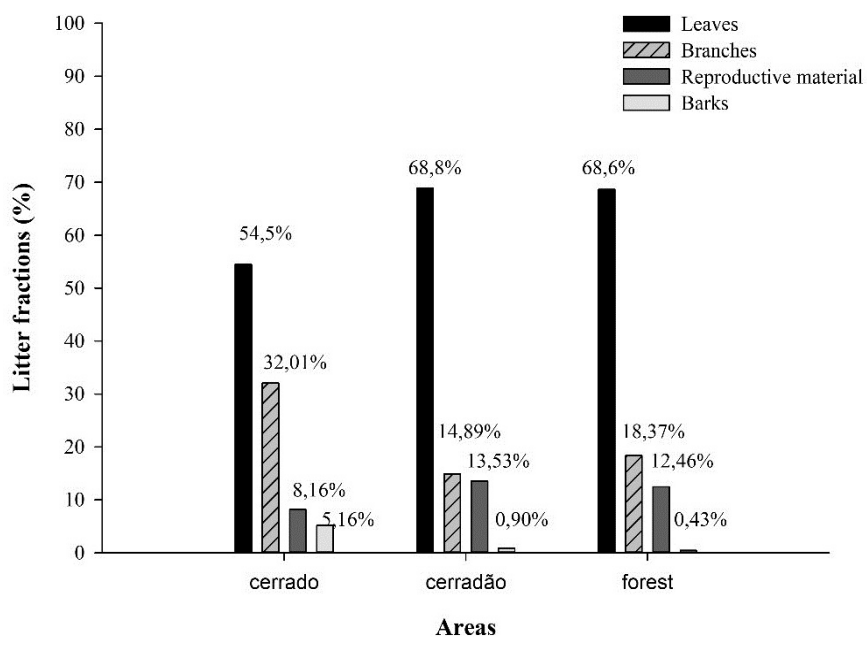

Figure 6. Percentage values from the total deposition of litter fractions in cerrado, cerradão and forest areas in southern Amazonas during the period from April 2018 to March 2019. 
to Calvi et al. (2009), the leaf fraction usually participates in a greater proportion in the litter biomass. However, the magnitude of this contribution mainly depends on the species, location structure and on how old the trees are (Nascimento et al., 2015). Bianchi et al. (2016) found a direct relation between the litter input and the canopy development. Based on these data, it can be inferred that the greater litter deposition in the cerradão and forest areas occurs due to the greater number of individuals, the proximity between them and, consequently, the greater coverage of the area in comparison to the cerrado environment (Campos et al., 2008).

Concerning the temporal variation of the litter fractions, there was a greater deposition of leaf material in the dry period. The month of greatest deposition of this fraction was August (Figure 7A). The higher leaf deposition value in August is compatible with the observed by Campos et al. (2008) in a study conducted in a fragment of cerrado stricto sensu.
One of the factors for the occurrence of this phenomenon may be related to the resistance mechanism from some plants to the water stress that, for avoiding water loss through transpiration, deposit a large amount of leaves in this period, thus reducing the water need (Marques et al ., 2017). Litter production studies conducted by Nascimento et al. (2015); Ourique et al. (2016); Aquino et al. (2016); Moura et al. (2016); Brasil et al. (2017) and Marques et al. (2017) also observed the maximum litter production in the dry period.

Furthermore, it is known that several cerrado species are deciduous, with the largest input occurring in the dry period of the year (Valentini et al., 2014). Deciduous species are also common in the cerradão. As according to Bianchi et al. (2016), even though they may be perennial, many species common to cerradão show deciduousness in certain periods of the dry season. On the other hand, tropical forests

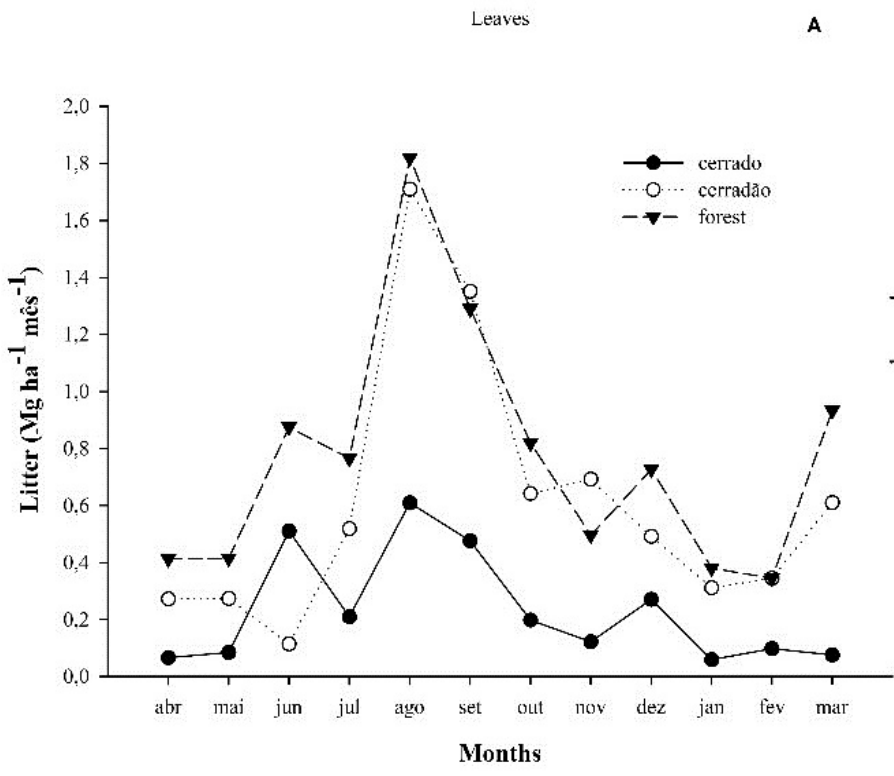

Reproductive materia

C

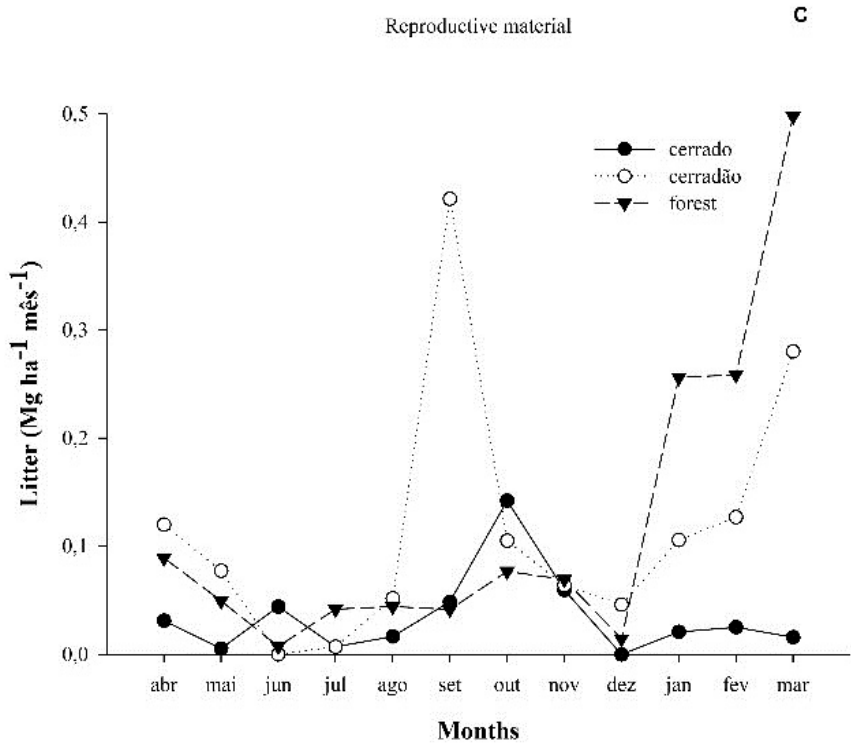

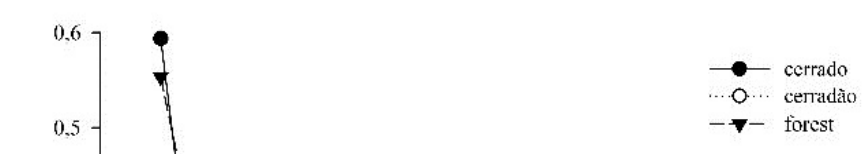

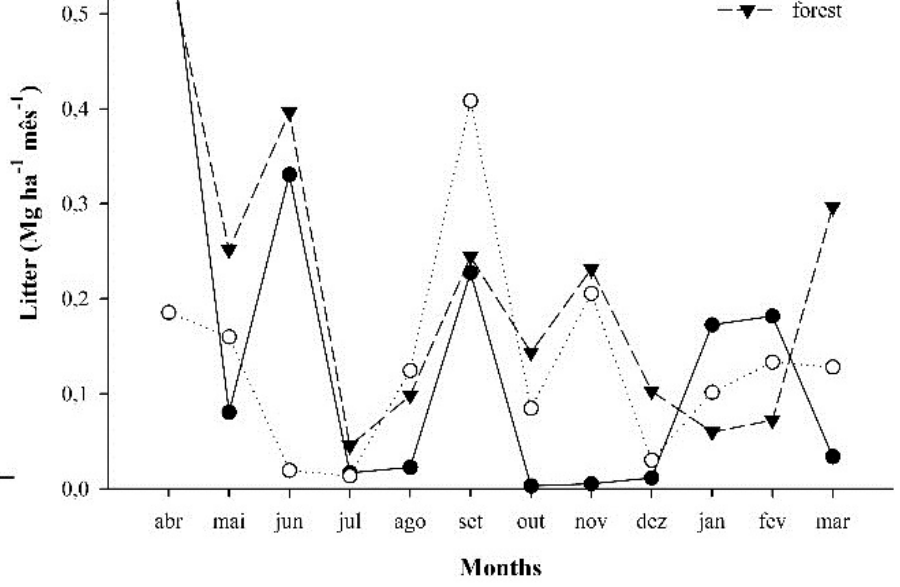

D

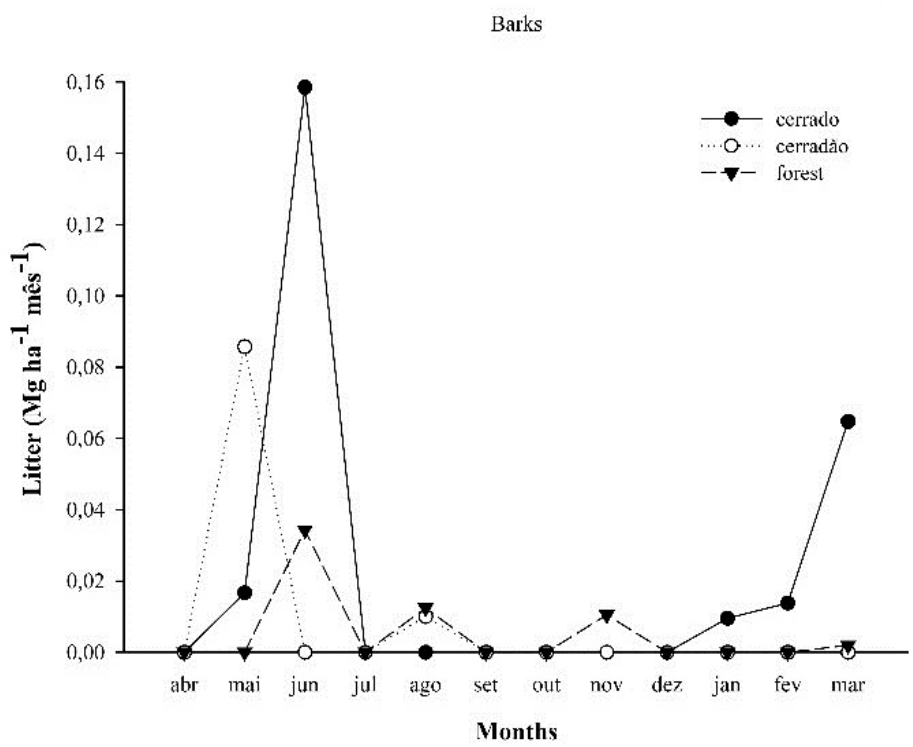

Figure 7. Monthly mean from the fractions of leaves, branches, reproductive material and barks in the different study areas from February 2018 to March 2019. A- Leaves; B- Branches; C- Reproductive material; D- Barks. 
have a wide variation between their species, impairing the determination of whether they are evergreen or deciduous.

One hypothesis for the higher value of the branches input in the cerrado and forest areas in April (Figure 7B) may be related to damage caused to the vegetation due to the rains in this month (Figure 2), causing this structure to detach from the trees. Konig et al. (2002) also reported that the input from variable branches amounts could be attributed to adverse climatic phenomena occurrences, such as storms with abnormal winds.

Regarding the reproductive material input, its intensity in the forest area was verified. Moreover, its largest inputs were during the rainy season, in January and February, reaching its maximum production value in March. While for cerradão and cerrado, the largest input of this fraction was in September and October, respectively, the dry period of the study region. However, the observed for all areas was that the production occurred throughout the year, but with variable quantities (Figure 7C), suggesting that the reproductive material deposition is linked to the dispersion strategy adopted by the species for their reproduction and does not depend only on microclimate variations (Holanda et al., 2017).

According to Giácomo et al. (2012), each fraction proportion in litter is possibly related to the phenology of the species present in each area, which would result in a varied distribution in each fraction proportion.

When analyzing the bark fraction, a greater input was verified during May in the cerradão, while the highest production was estimated in June in the cerrado and in the forest (Figure 7D). However, for better explanations, monitoring the phenological behavior of the species during the collection stage is necessary, aiming to collect data that can help explaining the obtained results, and even determine the isolated influence of each species for a certain event occurred in the production process (Nascimento et al., 2015). In this regard, for conducting studies with the same focus as this one, we propose a previous floristic survey of the areas under study.

\section{Conclusions}

Litter deposition, for the forest and cerradão areas, is superior to the cerrado area, with the same verified for all areas from this study, together with the greater deposition in a period of water scarcity, with the leaf fraction contributing the highest percentage. This phenomenon can be related to the adjustment of the plants in order to prevent water loss through transpiration.

\section{Literature Cited}

Almeida, E.J.; Luizao, F.; Rodrigues, D.J. Litterfall production in intact and selectively logged forests in southern of Amazonia as a function of basal area of vegetation and plant density. Acta Amazonica. v.45, n.2, p.157-166, 2015. https://doi. org/10.1590/1809-4392201402543.
Antoneli, V.; Francisquini, V. Influência de alguns elementos climáticos na produção de serrapilheira em um reflorestamento de pinus na FLONA (Floresta Nacional) de Irati- PR. Caderno de Geografia, v.25, n.44, p.176-190. 2015. https://doi.org/10.5752/p.23182962.2015v25n.44p.16.

Aquino, P.S.R.; Nappo, M.E.; Rodrigues, M.S.; Pereira, I.M.; Matricardi, E.A.T.; Pelá, G.M. Análise espacial da produtividade de serapilheira em uma mata de galeria. Ciência Florestal. v.26, n.2, p.489-500. 2016. https://doi.org/10.5902/1980509822749.

Bianchi, M.O.; Scoriza, R.N.; Correia, M.E.F. Influência do clima na dinâmica de serrapilheira em uma floresta estacional semidecidual em Valença, RJ, Brasil. Revista Brasileira de Biociências. v.14, n.2, p.97-101. 2016. http://ufrgs.br/seerbio/ ojs/index.php/rbb/article/view/3377. 29 Jun. 2019.

Brasil, J.B.; Andrade, E.M.; Aquino, D.N.; Resende, L.; Pereira Júnior, L.R. Sazonalidade na produção de serrapilheira em dois manejos no semiárido Tropical. Journal of Environmental Analysis and Progress, v.2, n.3, p.167-176, 2017. https://doi.org/10.24221/ jeap.2.3.2017.1335.167-176.

Brasil. Ministério das Minas e Energia. Projeto Radambrasil, folha SB. 21, Tapajós. Rio de Janeiro: Radambrasil, 1978. 561p.

Braun, E.H.G.; Ramos, J.R.A. Estudo agroecológico dos campos Puciarí-Humaitá (Estado do Amazonas e Território Federal de Rondônia). Revista Brasileira de Geografia, v.21, n.4, p.443-497, 1959. https://biblioteca.ibge.gov.br/visualizacao/ periodicos/115/rbg_1959_v21_n4.pdf. 12 Abr. 2019.

Calvi, G.P.; Pereira, M.G.; Júnior, A.E. Produção de serapilheira e aporte de nutrientes em áreas de floresta atlântica em Santa Maria de Jetibá, ES. Ciência Florestal, v.19, n.2, p.131-138, 2009. https://doi.org/10.5902/19805098404.

Campos, E.H.; Alves, R.R.; Serato, D.S.; Rodrigues, S.C. Acúmulo de serrapilheira em fragmentos de mata mesofítica e cerrado stricto sensu em Uberlândia MG. Sociedade \& Natureza, v.20, n.1, p.189203, 2008. https://doi.org/10.1590/S1982-45132008000100013.

Campos, M.C.C.; Ribeiro, M.R.; Júnior, V.S.S.; Filho, M.R.R.; Almeida, M.C. Topossequência de solos na transição campos naturais-floresta na região de Humaitá, Amazonas. Acta Amazônia, v.42, n.3, p.387398, 2012. https://doi.org/10.1590/S004 4-59672012000300011.

Campos, M.C.C.; Ribeiro, M.R.; Souza Junior, V.S.; Ribeiro Filho, M.R.; Costa, E. U.C. Interferencias dos pedoambientes nos atributos do solo em uma topossequencia de transicao Campos/Floresta. Revista Ciência Agronômica, v.41, n.4, p.527-535, 2010. https:// doi.org/10.1590/S1806-66902010000400004.

Giácomo, R.G.; Pereira, M.G.; Machado, D.L. Aporte e decomposição de serapilheira em áreas de cerradão e mata mesofítica na estação ecológica de pirapitinga - MG. Ciência Florestal, v.22, n.4, p.669-680, 2012. https://doi.org/10.5902/198050987549.

Holanda, A.C.; Feliciano, A.L.P.; Freire, F.J.; Sousa, F.Q.; Freire, S.R. O.; Alves, A.R. Aporte de serapilheira e nutrientes em uma área de caatinga. Ciência Florestal, v.27, n.2, p.621-633, 2017. https:// doi.org/10.5902/1980509827747.

Konig, G.K.; Schumacher, M.V.; Brun, E.J.; Deling, I. Avaliação da sazonalidade da produção de serapilheira numa floresta estacional decidual no município de Santa Maria-RS. Revista Árvore, v.26, n.4, p.429-435, 2002. https://doi.org/10.1590/ S0100-67622002000400005. 
Malhi, Y.C.E.; Doughty, C.E.; Goldsmith, G.R.; Metcalfe, D.B.; Girardin, C.A.J.; Marthews, T.R.; Aguila-Pasquel, J.; Aragão, L.E.O.C.; Araujo-Murakami, A.; Brando, P.; Costa, A.C.L.; Silva-Espejo, J.E.; Amézquita, F.F.; Galbraith, D.R.; Quesada, C.A.; Rocha, W.; Salinas-Revilla, N.; Silvério, D.; Meir, P.; Phillips, O. L. The linkages between photosynthesis, productivity, growth and biomass in lowland Amazonian forests. Global Change Biology, v.21, n.6, p.2283-2295, 2015. https://doi.org/10.1111/gcb.12859.

Marques, A.C.A.; Junior, O.B.P.; Vourlitis, G.L. Avaliação de produção de serapilheira em planície inundável no Pantanal MatoGrossense. Ensaios e Ciência: Biológicas, Agrárias e da Saúde, v.21, n.3, p.148-151, 2017. https://doi.org/10.17921/14156938.2017v21n3p148-151.

Matos, N.M.; Ribeiro, F.P.; Gatto, A.; Bussinguer, A.P. Estoque de serapilheira em três fisionomias no Cerrado do Distrito Federal. Floresta e Ambiente, v.24, n.1, p.09-09, 2017. https://doi. org/10.1590/2179-8087.126215.

Moura, M.M.S.; Costa, G.B.R.; Palácio, H.A.Q.; Araujo Neto, J.R.; Brasil, J.B. Produção de serapilheira e suas frações em área da Caatinga no Semiárido Tropical. Revista Brasileira de Gestão Ambiental e Sustentabilidade. v.3, n.5, p.199-208, 2016. https:// doi.org/10.21438/rbgas.030509.

Nascimento, LS.; Cerqueira, R.S.; Henderson, B.L.R. Produção de serapilheira em um fragmento adjacente a uma cava de mineração, Ribeirão Grande, SP. Revista Brasileira de Engenharia Agrícola e Ambiental. v.19, n.9, p.892-897, 2015. https://doi. org/10.1590/1807-1929/agriambi.v19n9p892-897.

Ourique, L.K.; Silva, R.O.; Souza, C.A.S.; Noguchi, H.; Santos, J.; Higuchi, N. Relação da produção de serapilheira com incremento em diâmetro de uma floresta madura na Amazônia Central. Scientia Forestalis, v. 44, n.112, p.875-886, 2016. https://doi. org/10.18671/scifor.v44n112.09.

Quesada, C.A.; Lloyd, J.; Anderson, L.O.; Fyllas, N.M.; Schwarz, M.; Czimczik, C.I. Soils of Amazonia with particular reference to the RAINFOR sites. Biogeosciences, v.8, n.6, p.1415-1440, 2016. https://doi.org/10.5194/bg-8-1415-2011.
Santos, L.A.C.; Campos, M.C.C.; Costa, H.S.; Pereira, A.R. Caracterização de solos em uma topossequência sob terraços aluviais na região do médio rio Madeira (AM). Ambiência, v.8, n.2, p.319-331, 2012. https://doi.org/10.5777/ambiencia.2012.02.07.

Silva, C.J, Lobo, F.A, Bleich, M.E, Sanches L. Contribuição de folhas na formação da serrapilheira e no retorno de nutrientes em floresta de transição no norte de Mato Grosso. Acta Amazônica, v.39, n.3, p.591-600, 2009. https://doi.org/10.1590/S004459672009000300014.

Silva, C.J; Sanches, L.; Lobo, F.A.; Nogueira, J.S. Produção de serrapilheira no Cerrado e floresta de transição amazônicaCerrado do centro-oeste brasileiro. Acta Amazônica, v.37, n.4, p.543-548, 2007. https://doi.org/10.1590/S004459672007000400009.

Silva, F.B.; Shimabukuro, Y.E.; Aragão, L.E.O.C.; Anderson, L.O.; Pereira, G.; Cardozo, F.; Arai, E. Corrigendum: Large-scale heterogeneity of Amazonian phenology revealed from 26-year long AVHRR/ NDVI time-series. Environmental Research Letters, v.8, n.2, p.112, 2013. https://doi.org/10.1088/1748-9326/8/2/029502.

Valentini, C.M.A.; Soares, G.S.; Santana R.A.; Guimarães, A.F.S.; Silva, A.H.B. Produção, acúmulo e decomposição de serapilheira em uma área revegetada do parque estadual Massairo Okamura em Mato Grosso. Holos, v.30, n.5, 2014. https://doi.org/10.15628/ holos.2014.1397.

Vidotto, E.; Pessenda, L.C.R.; Ribeiro, A.S.; Freitas, H.A.; Bendassolli, J.A. Dinâmica do ecótono floresta-campo no sul do estado do Amazonas no Holoceno, através de estudos isotópicos e fitossociológicos. Acta Amazônica, v.37, n.3, p.1-24. 2007. https://doi.org/10.1590/S0044-59672007000300010.

Yanai, A.M.; Fearnside, P.M.; Graça, P.M.L.A. Desmatamento no sul do Amazonas: simulação do efeito da criação da Reserva de Desenvolvimento Sustentável do Juma. In: Simpósio Brasileiro de Sensoriamento Remoto, 15., 2011, Curitiba. Anais... Curitiba: Sociedade Brasileira de Sensoriamento Remoto; INPE, 2011. p.6193-6200. http://marte.sid.inpe.br/col/dpi.inpe.br/ marte/2011/06.27.17.00/doc/p1076.pdf. 19 Jan. 2019. 